\section{FINANCIAL INCLUSION THROUGH REGIONAL RURAL BANKS AND EMPOWERIMENT OF WEAKER SECTIONS - A STUDY IN TUMIKUR DISTRICT}

\section{KEY WORDS: Financial}

Inclusion, Regional Rural Banks Financial needs, Empowerment, Weaker Sections, Standard of Living and Cauvery Kalpatharu Grameena Bank (CKGB).

\title{
Mr.
}

\section{Thirumalesha}

\section{Babu T R}

Assistant Professor, Department of Sociology, Government First Grade College, Koratagere,Tumakuru, Karnataka-572 129.

The issue of financial inclusion is emerging as the new paradigm of economic growth. Financial inclusion plays a major role in driving a way the poverty from the country. Financial inclusion refers to delivery banking services to masses including privileged and disadvantaged people at an affordable terms and conditions. It not only enhances overall financial intensity of agriculture but also help in increasing rural nonfarm activities which lead to development of rural economy and improve economic condition of people. Regional Rural Banks are also entered to strengthen the financial inclusion network in rural areas.

\section{INTRODUCTION}

In India rural people such as small and marginal farmers, landless agricultural laborers, artisans and socially and economically backward castes and classes they have been exploited in the name of credit facility by informal sector. The rural credit market consists of both formal and informal financial institutions and agencies that meet the credit needs of the rural masses in India. The supply of total formal credit is inadequate and rural credit markets are imperfect and fragmented. Moreover, the distribution of formal sector credit has been unequal, particularly with respect to region and class, cast and gender in the country side.

Regional Rural Banks were established under the provisions of an Ordinance promulgated on the 26th September 1975 and the RRB Act, 1975 with an objective to ensure sufficient institutional credit for agriculture and other rural sectors. The RRBs mobilize financial resources from rural/semi-urban areas and grant loans and advances mostly to small and marginal farmers, agricultural laborers and rural artisans. For the purpose of classification of bank branches, the Reserve bank of India defines rural area as a place with a population of less than 10,000. RRBs are jointly owned by Government of India, the concerned State Government and Sponsor Banks; the issued capital of a RRB is shared by the owners in the proportion of $50 \%, 15 \%$ and $35 \%$ respectively.

\section{Objectives OfThe Study}

1.To study the growth and performance of financial inclusion through Regional Rural Banks.

2. To analyse the role of Regional Rural Banks in catering the Financial needs of the weaker sections of the society.

3 . To examine the impact of Regional Rural Banks specially Cauvery Kalpatharu Grameena Bank on the development of weaker sections in Tumkur District.

4. To evaluate the improvement of standard of living and livelihood security of the weaker sections of the society after post-loan period in the study area.

5. To suggest suitable measures for the further effective functioning of Regional Rural Banks in catering the financial needs of the weaker sections

\section{METHODOLOGY}

The present study is based on both secondary and primary sources of data. The secondary data has been collected from the journals, government reports, NABARD documents, SLBC reports, District Lead Bank Office, Tumkur District, Cauvery Kalpatharu Grameena Bank Annual Reports, ISEC Library, NIRD and RBI reports. The primary data has been collected from 350 respondents in Tumkur District. The sample respondents have been chosen on simple random sampling basis. The data analysis has been carried out by using simple statistical methods like percentages and averages; this will help us to understand the gross root level realites. One sample t-test and Anova test has been used. The primary information has been collected by adapting standard questionnaire. The field survey was conducted mainly in three taluks viz., namely Pavagada, Sira and Madhugiri taluks respectively.

\section{RESULTS AND DISCUSSION}

The primary objective of the bank is to uplift the weaker sections of the society in rural areas. Nearly 60 to 70 percent of the rural poor belong to weaker sections like scheduled castes, scheduled tribes and some portion of the backward classes. Development of these classes would lead to the development of the rural areas. To know which class is given more importance by the bank while sanctioning the loans, the researcher classified the total sample respondents based on their castes. Table -1 . Shows the category-wise classification of sample households. Out of the total 350 respondents selected for the study, 25 respondents are scheduled tribe, while 75 belong to scheduled caste.

Table - 1 Category-wise Classification Of Sample Respondents

\begin{tabular}{|l|l|l|l|l|l|}
\hline $\begin{array}{l}\text { Name of } \\
\text { the } \\
\text { Branch }\end{array}$ & $\begin{array}{l}\text { Schedule } \\
\text { d Caste }\end{array}$ & $\begin{array}{l}\text { Schedul } \\
\text { ed Tribe }\end{array}$ & $\begin{array}{l}\text { Backward } \\
\text { Caste }\end{array}$ & Others & Total \\
\hline Pavagada Taluk & \multicolumn{5}{|l|}{} \\
\hline C.K.Pura & 12 & 18 & 20 & 28 & 68 \\
\hline Sira Taluk \\
\hline $\begin{array}{l}\text { Honnagon } \\
\text { danahalli }\end{array}$ & 10 & 5 & 10 & 22 & 47 \\
\hline Banagere & 11 & 3 & 14 & 20 & 48 \\
\hline Madhugiri Taluk & 4 & 30 & 30 & 84 \\
\hline Midigesi & 20 & 4 & 26 & 50 & 103 \\
\hline $\begin{array}{l}\text { Badavanah } \\
\text { alli }\end{array}$ & 22 & 5 & 100 & 150 & 350 \\
\hline Total & 75 & 25 & & & \\
\hline
\end{tabular}

Out of the 350 respondents about 150 respondents are other castes and 100 respondents hail from backward classes. The branch-wise data reveals that, backward classes are more in Midigesi branch, when compared to other branches. More respondents from other categories have got the loan from Badavanahalli branch. Scheduled caste and scheduled tribe respondents could not exceed 16.18 percent and 4.48 percent respectively. It indicates that the bank usually concentrated more on other castes and backward caste. The reason is that, majority of the loans are crop loans and major portion of the lands are owned by the other communities and backward classes. And the bank also has felt that repaying capacity is more in these categories. Most of the scheduled caste and scheduled tribe respondents have got the loans under special schemes like Scheduled Caste Action Plan (SCAP), Scheduled Tribe Action Plan (STAP), Self Help Groups (SHGs), 
Prime Minister RozgarYojana (PMRY).

\section{Distribution Of Sample Respondents By Occupation}

Branches of CKGP in all the service areas sanction the loans to both priority and non-priority sectors. In all the branches under study, respondents belonging to different categories and occupations have taken the loans and advances. To carry out the analysis and interpretation, respondents have been classified into five categories. They are agriculturists, agriculture laborers, rural artisans, small business and others. Table indicates the distribution of the selected households according to their occupations. It is evident that out of the 350 sample respondents, 100 (51.19 percent) respondents are agriculturists whereas 70 respondents are agricultural labourers. Artisans and small business constitute only 113 and 25 respondents respectively. In C.K.Pura, Midigesi and Badavanahalli branch areas, the percentage of agriculturists and agricultural labour is more. But in the cases of Honnagondanahalli and Banagere branches only 15 and 10 respondents from agriculturists have been provided the agriculture loans. The reason is that respondents depending on agricultural activities are less in number in Honnagondanahalli and Banagere areas. In almost all the branches, rural artisans have occupied second place in getting the loans. On an average it is understood that bank has given more loans to agricultural dependents under crop loans scheme.

Table - 2 Distribution Of Sample Respondents By Occupation

\begin{tabular}{|l|l|l|l|l|l|l|}
\hline $\begin{array}{l}\text { Name } \\
\text { of the } \\
\text { Branch }\end{array}$ & $\begin{array}{l}\text { Agricu } \\
\text { lturists }\end{array}$ & $\begin{array}{l}\text { Agri- } \\
\text { Labour }\end{array}$ & $\begin{array}{l}\text { Artisa } \\
\text { ns }\end{array}$ & $\begin{array}{l}\text { Small- } \\
\text { Busine } \\
\text { ss }\end{array}$ & Others & Total \\
\hline $\begin{array}{l}\text { C.K.Pur } \\
\text { a }\end{array}$ & $\begin{array}{l}20 \\
(59.57)\end{array}$ & $\begin{array}{l}14 \\
(10.64)\end{array}$ & $\begin{array}{l}12 \\
(12.06)\end{array}$ & $\begin{array}{l}5 \\
(6.38)\end{array}$ & $\begin{array}{l}13 \\
(11.35)\end{array}$ & $\begin{array}{l}64 \\
(100)\end{array}$ \\
\hline $\begin{array}{l}\text { Honnag } \\
\text { ondana } \\
\text { halli }\end{array}$ & $\begin{array}{l}15 \\
(22.39)\end{array}$ & $\begin{array}{l}10 \\
(17.91)\end{array}$ & $\begin{array}{l}15 \\
(31.34)\end{array}$ & $\begin{array}{l}3 \\
(10.45)\end{array}$ & $\begin{array}{l}10 \\
(17.91)\end{array}$ & $\begin{array}{l}53 \\
(100)\end{array}$ \\
\hline $\begin{array}{l}\text { Banage } \\
\text { re }\end{array}$ & $\begin{array}{l}10 \\
(16.18)\end{array}$ & $\begin{array}{l}9 \\
(13.23)\end{array}$ & $\begin{array}{l}(22.06) \\
(23.53)\end{array}$ & $\begin{array}{l}14 \\
(25.00)\end{array}$ & $\begin{array}{l}10 \\
(100)\end{array}$ \\
\hline $\begin{array}{l}\text { Midige } \\
\text { si }\end{array}$ & $\begin{array}{l}25 \\
(53.27)\end{array}$ & $\begin{array}{l}17 \\
(9.55)\end{array}$ & $\begin{array}{l}29 \\
(21.10)\end{array}$ & $\begin{array}{l}5 \\
(6.03)\end{array}$ & $\begin{array}{l}16 \\
(10.05)\end{array}$ & $\begin{array}{l}92 \\
(100)\end{array}$ \\
\hline $\begin{array}{l}\text { Badava } \\
\text { nahalli }\end{array}$ & $\begin{array}{l}30 \\
(64.82)\end{array}$ & $\begin{array}{l}20 \\
(10.6)\end{array}$ & $\begin{array}{l}16 \\
(9.05)\end{array}$ & $\begin{array}{l}2 \\
(3.01)\end{array}$ & $\begin{array}{l}22 \\
(12.06)\end{array}$ & $\begin{array}{l}90 \\
(100)\end{array}$ \\
\hline Total & $\begin{array}{l}100 \\
(28.56)\end{array}$ & $\begin{array}{l}70 \\
(20)\end{array}$ & $\begin{array}{l}80 \\
(22.86)\end{array}$ & $\begin{array}{l}25 \\
(7.15)\end{array}$ & $\begin{array}{l}75 \\
(21.43)\end{array}$ & $\begin{array}{l}350 \\
(100)\end{array}$ \\
\hline
\end{tabular}

To test the relationship between location of branches and disbursement of loans to various occupational groups null hypotheses is formulated and Chi-square testl is applied. Chi-square value is 102.39. Table value at $5 \%$ level of significance for 4 degrees of freedom is 24.996. Since the calculated value is greater than the table value, there is significant difference between the sample branches and occupations of the sample households. Hence, a null hypothesis (Branches location doesn't significantly influence the disbursement of loans by occupation) is rejected. In other words, branch location influence the distribution of loans by occupation.

\section{Awareness of Respondents on Loan Portfolio}

Table -3 reveals the beneficiary awareness regarding the different types of loans in selected branches of CKGB. It reveals that out of the 350 respondents, 50 percent of respondents have the knowledge and awareness on different kinds of loans issued by the bank. This trend can be observed in all the branches.

About 35.71 percent of respondents are partly aware of the types of loans. Only 14.29 percent of households are not aware of different types of loans issued by the CKGP. In the case of Banagere branch, no beneficiary is found unaware of different kinds of loans.
Table - 3respondent's Awareness Regarding The Different Types Of Loans Of CKGB

\begin{tabular}{|l|l|l|l|l|}
\hline $\begin{array}{l}\text { Name of } \\
\text { the } \\
\text { branch }\end{array}$ & Aware & $\begin{array}{l}\text { Partly } \\
\text { aware }\end{array}$ & Unaware & Total \\
\hline C.K.Pura & 35 & 20 & 6 & 61 \\
\hline $\begin{array}{l}\text { Honnagon } \\
\text { danahalli }\end{array}$ & 15 & 15 & 4 & 34 \\
\hline Banagere & 20 & 10 & - & 30 \\
\hline Midigesi & 55 & 30 & 10 & 95 \\
\hline $\begin{array}{l}\text { Badavanah } \\
\text { alli }\end{array}$ & 50 & 50 & 30 & 130 \\
\hline Total & $175(50.00)$ & $125(35.71)$ & $50(14.29)$ & $350(100)$ \\
\hline
\end{tabular}

\section{Utilization And Diversification Of Loans}

Development of people is depending not only on sanctioning of loans but also on the utilization of that loan in a proper way. If people divert their loan towards the unproductive areas, the objectives of the bank would not be achieved and the development would not be seen. Table -4 shows the utilization and diversification of loans by the beneficiaries in the sample branches. It is observed that out of the total 350 beneficiaries, 150 (42.85 percent) beneficiaries among all the branches could not utilize the loan properly. Out of the total number of sample branches, highest i.e., 50 of respondents in Midigesi branch have not utilized the loan properly. Conversely, in C.K.Pura branch, highest of 51.7730 respondents diversified their loan amounts to various other purposes. The reasons like untimely issue of loan amount, illness, inadequate of loan amount, payment of old debts, heavy family expenditure are found important which heavily influenced the household to divert the loan to other purposes.

Table- 4 Utilization And Diversification Of Loans

\begin{tabular}{|l|l|l|l|}
\hline $\begin{array}{l}\text { Name of the } \\
\text { branch }\end{array}$ & Diversified & Utilized & Total \\
\hline C.K.Pura & 30 & 40 & 70 \\
\hline $\begin{array}{l}\text { Honnagondana } \\
\text { halli }\end{array}$ & 15 & 20 & 35 \\
\hline Banagere & 10 & 30 & 40 \\
\hline Midigesi & 50 & 50 & 100 \\
\hline Badavanahalli & 45 & 60 & 105 \\
\hline Total & $150(42.85)$ & $200(57.15)$ & $350(100)$ \\
\hline
\end{tabular}

\section{Impact Of CKGB Financing OnWeaker Sections}

The impact of loans has been assessed in terms of the average incomes. In other words, the average incomes of the beneficiaries from different sectors before and after taking the loan are measured. As may be seen from the table- 5 an increase in the average incomes of the beneficiaries was noticed in all the sectors after taking the loan.

But the increment in the incomes is varied from sector to sector. More improvement in the income levels may be observed in the small business sector with 28.47 percent change in the average income, followed by artisans with 14.77 percent change.

Though there has been an improvement in the income levels among the agriculturists and agricultural laborers, their proportionate change has not been satisfactory when compared to small business and rural artisans. Pathetically, change in the agriculturists income is less than the change in the incomes of agricultural labourer's even.

The reason is that the agriculturists are completely depending on agriculture. The total family expenditures would be met from agricultural incomes only, they fell in debt in the case of crop failures.

This condition might be continued for one to two years in certain times. On an average, an increase in income levels of the beneficiaries with varied proportions may be observed. 


\begin{tabular}{|c|c|c|c|c|c|}
\hline \multicolumn{6}{|c|}{$\begin{array}{l}\text { Table - } 5 \text { Pre and Post-Loan Aver } \\
\text { Position of Beneficiary Households }\end{array}$} \\
\hline \multicolumn{6}{|c|}{ Pre-Loan Average Annual Income } \\
\hline $\begin{array}{l}\text { Name of } \\
\text { the } \\
\text { branch } \\
\end{array}$ & $\begin{array}{l}\text { Agricult } \\
\text { urists }\end{array}$ & \begin{tabular}{|l|} 
Agri- \\
labour
\end{tabular} & Artisans & \begin{tabular}{|l|} 
Small \\
Business
\end{tabular} & Others \\
\hline C.K.Pura & 12250 & 8200 & 9247 & 15400 & 9100 \\
\hline $\begin{array}{l}\text { Honnago } \\
\text { ndanahal } \\
\text { li }\end{array}$ & 9600 & 7400 & 8700 & 13143 & 7950 \\
\hline $\begin{array}{l}\text { Banager } \\
\mathrm{e}\end{array}$ & 10150 & 7947 & 7147 & 14950 & 8459 \\
\hline Midigesi & 9400 & 6200 & 13400 & 12100 & 9429 \\
\hline $\begin{array}{l}\text { Badavan } \\
\text { ahalli }\end{array}$ & 8650 & 5900 & 7500 & 11200 & 8149 \\
\hline Total & 50050 & 35647 & 45994 & 66973 & 43087 \\
\hline $\begin{array}{l}\text { Average } \\
\text { Income }\end{array}$ & 10010 & 7129.40 & 9198.80 & 13358.60 & 8617.40 \\
\hline
\end{tabular}

Table- 6 Post-Loan Average Annual Income

\begin{tabular}{|l|l|l|l|l|l|}
\hline \multicolumn{6}{|l|}{ Post-Loan Average Annual Income } \\
\hline $\begin{array}{l}\text { Name of } \\
\text { the } \\
\text { branch }\end{array}$ & $\begin{array}{l}\text { Agricult } \\
\text { urists }\end{array}$ & $\begin{array}{l}\text { Agri- } \\
\text { labour }\end{array}$ & Artisans & $\begin{array}{l}\text { Small } \\
\text { Business }\end{array}$ & Others \\
\hline C.K.Pura & 13150 & 8346 & 10200 & 21200 & 10500 \\
\hline $\begin{array}{l}\text { Honnago } \\
\text { ndanahal } \\
\text { li }\end{array}$ & 9900 & 8150 & 9829 & 14143 & 8050 \\
\hline $\begin{array}{l}\text { Banager } \\
\text { e }\end{array}$ & 11200 & 8944 & 8947 & 19200 & 8400 \\
\hline Midigesi & 9550 & 7116 & 14812 & 18167 & 10100 \\
\hline $\begin{array}{l}\text { Badavan } \\
\text { ahalli }\end{array}$ & 9109 & 6100 & 9000 & 13100 & 8288 \\
\hline Total & 52909 & 38656 & 52788 & 85810 & 45338 \\
\hline $\begin{array}{l}\text { Average } \\
\text { Income }\end{array}$ & 10581.80 & 7731.20 & 10557.60 & 17162.00 & 9067.60 \\
\hline & 5.72 & 8.44 & 14.77 & 28.47 & 5.22 \\
\hline
\end{tabular}

\section{Impact On Standard Of Living}

Standard of living is one of the important measurements to assess the development of the people. Ina developing country like India, agriculture plays vital role in upgrading the living standards of the rural poor.

Non-availability of timely and adequate credit are considered as important factors for low productivity and it leads to low standard of living. The researcher has collected the data from the sample respondents regarding their standard of living before and after utilization of the loan.

Table -7 reveals the information relating to the standard of living of the sample beneficiaries after the loan is utilized. It is apparent that only 75 (21.43 percent) households have improved their standard of living.

About 28.57 percent have expressed that there was no change in their standard of living even after utilizing the loan also. About 48.81 percent of sample beneficiaries opined that they have moderately improved.

Brach-wise data reveals that the standard of living is improved in Midigesi when compared to the other branches. Second to Midigesi in Banagere.

Least improvement is seen in C.K.Pura and Badavanahalli branches. Most of the beneficiaries in Midigesi, Banagere and Honnagondanahalli are artisans and also depending on small businesses.

They could improve their income levels. But in the cases of C.K.Pura and Badavanahalli branches, beneficiaries depend on agriculture. They could not develop adequately.
Table - 7 Standard Of Living Of The Sample Respondents After Utilizing The Loan

\begin{tabular}{|l|l|l|l|l|}
\hline $\begin{array}{l}\text { Name of the } \\
\text { branch }\end{array}$ & $\begin{array}{l}\text { Improve } \\
\text { d }\end{array}$ & $\begin{array}{l}\text { Moderately } \\
\text { Increased }\end{array}$ & $\begin{array}{l}\text { Remain } \\
\text { Unchanged }\end{array}$ & Total \\
\hline C.K.Pura & 15 & 35 & 15 & 65 \\
\hline $\begin{array}{l}\text { Honnagondan } \\
\text { ahalli }\end{array}$ & 4 & 20 & 5 & 29 \\
\hline Banagere & 6 & 15 & 10 & 31 \\
\hline Midigesi & 30 & 45 & 30 & 105 \\
\hline Badavanahalli & 20 & 60 & 40 & 120 \\
\hline Total & $75(21.43)$ & $175(50.00)$ & $100(28.57)$ & $350(100)$ \\
\hline
\end{tabular}

\section{Major Findings Of The Study}

- The Credit Deposit ration of CKGB is well above the national average of all RRBs in India. But, it registered a declining trend over the period under reference. This is a disturbing trend as the CKGB in not able to lend at the same pace of deposit mobilization. Subsequently, it reduced recycling of funds for the productive utilization by the region. A comparison of recovery performance of CKGB and national averages reveals that CKGB is far behind in the percentages of recovery in the priority sector and non-priority sector, recovery performance is relatively more in non-priority sector when compared to the priority sector.

- CKGB has initiated measures like streamlining the information system on recoveries, introduction of a scheme of awards for recognizing high level of recovery performance by all cadres of staff, publication of Monthly Recovery Bulletin availing the services of Vikas Valunteer Vahini Clubs, initiation of legal action and allocation of branch-wise quarterly recovery targets.

- Term deposits occupied prime place in total deposits of all the sample branches.

- Analysis of loan portfolios of sample branches shows that priority sector advances are very high (80 to 90\%) in Badavanahalli, Midigesi and C K Pura branches and nonpriority sector advances are high (70 to $80 \%$ ) in Honnagondanahalli and Banagere branches. It is in accordance with the socio-economic aspects of the regions. Honnagondanahalli and Banagere regions depend less on agriculture and allied activities. Thus, nonpriority sector had apportioned major share of the advances. Most of the advances under priority sector are agriculture related. Advances by the bank to other sectors like SHGs and transportation are very less. The branches appear to cater to the conventional business only.

- Majority of the beneficiaries (80\%) belong to low income group of below Rs.15,000 per annum. It is found that there is no significant difference between the branches in the distribution of loans to the beneficiaries by income.

- An analysis of pre and post loan average annual incomes of beneficiaries shows betterment across all sections of beneficiaries. A rise in income is found to be substantial (28.47) in case of small business borrower's followed by artisans. The enhancement in income is too less in case of agriculture labourers and farmers. Uncertainty in yield from crops that are heavily monsoon dependent is the major reason for farmer's malady.

- In the opinion of majority of beneficiaries (75\%), there is moderate improvement in their standard of living after availing the loan from CKGB. The rural economy in this region is not experiencing considerable improvement as the infrastructure facilities have not grown and cities in search of better opportunities. Though the CKGB is financing for the rural credit requirements, it is not sufficient for improving their standard of living.

\section{CONCLUSION}

- Adequate credit shall be provided for the segments like rural artisans and cottage industries particularly as they have potential to generate employment opportunities.

- There is dire need to enhance the quantum of lending by CKGB so that needy people would be benefited. It also 
contributes to the adequate rural development. In a nutshell, the credit deposit ration of the bank shall be enhanced so as to consumerate the credit with the pace of deposits.

- During the survey some of the beneficiaries expressed that, they are getting the timely help from the bank officials in lending loans but not getting technical help in time. Hence, efforts should be made to recruit agriculture graduates as field officers $\backslash$ in all the branches to help the farmers in providing technical guidance in crop production.

- A specific procedure shall be followed in fixing the targets per year concerning the grounding of the units under any programme launched by CKGB. Viability of the project alone shall not be the criterion in sanctioning the loans. Loans can be sanctioned to the needy poor people so that the income levels of the weaker sections may be uplifted.

- The sample branches like Pavagada, Sira and C.K.Pura shall reduce loan portfolio towards priority sector advances. In other words, the quantum of advances shall be increased to non-priority sector to maintain the parity between priority and non-priority sector advances.

\section{REFERENCES}

1) A Hand Book of Community Development (1958), London: Her Majesty's Stationery Office, p.2.

2) Archarya Shyama Charan \& Mohanty, Ashok Kumar (2006), Operational Analysis-Regional Rural Banks, Soujanaya Books.Delhi.

3) Bala Mohan Das, V., Prabhakar Rao., J.V. Hrushikesava Rao,p. (1991), Rural Banks and Rural Credit Discovery, Publishing House.

4) Balamohan Das, V. Prabhakar Rao, J.V. and Hrushi Kesava Rao, p. (1991), Rural Banks and Rural Credit,New Delhi:Discovery Publications, p. 1 .

5) Chandra Kanth K. Souara 91998), Regional Rural Banks in India, New Delhi: Anmol Publications, p.7.

6) Charan D. (1980), Wadhwa Rural Banking for Rural Development, Delhi: MacMillan Company.

7) Ghosal, S.N. (1972), Agricultural Financing in India, Asia Publishing House, New Delhi.

8) Giriappa,S. (1976), Urbanism and Rural Development, Bangalore:Institute for Social and Economic Change, p.19.

9) Harapal Sing (1974), Regional Rural Banks, Yojana,Vol.23.Dec.p.13.

10) Harapal Sing (1974Z), Regional Rural Banks, Yojana,Vol.23,Dec.p. 13

11) Krishnamaraju, S. (1992), Banking Finance and Rural Development, New Delhi:Discovery Publishing House.

12) Narayan, $\mathrm{N}$ and Chandrasekhar, G. (1988), Bank Credit and Rural Development- A Study of Utilization of Credit in Anatapur District, Ashish Publishing House, New Delhi.

13) Pany, R.K., (edited) (1988), Bank Finance for Rural Development, Seminar paper on Commercial Banks in Chittoor District, Ashis Publishing House, New Delhi.

14) Patnik, U.C. and Mishra, R.N(1993), Rural Banking in India, New Delhi: Anmol Publications Pvt., Ltd.

15) Popat, A.N. (1979), Recommendations of M.L.Dantwala Committee on RRBs, Bombay, p.10.

16) Priyan, A.K. (1995), Regional Rural Banks Rural Development, Arihant Publishing House.Jaipur.

17) Sanders, T.H (1958), The Community, NewYark: the Ronald Press Company, p.391.

18) Sandhu, B.S. (1996), Banking and Rural Development, Deep and Deep Publications. New Delhi.

19) Sandhu, B.S. (1996), Banking and Rural Development, New Delhi: Deep and Deep Publications, pp.60-61.

20) Shete, N.B. (1990), Regional Rural Banks an Analysis, Banking Finance, April, Vol.III,No.4,3

21) Sunil Kumar (1990), Regional Rural Banks and Rural Development, New Delhi: Deep and Deep Publications, p. 138

22) Uma Lele (1975), The Design of Rural Development Lessons from Africal, Baltimore:John Hopkins Press, p.25. 